UMR 5824

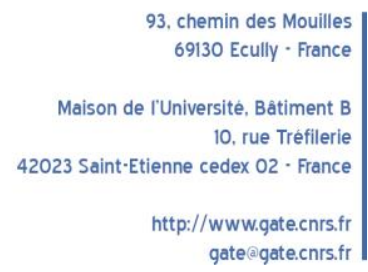

WP 1840 - December 2018

\title{
Piero Sraffa and the project to publish Saint- Simon's works
}

\author{
Michel Bellet, Adrien Lutz
}

\begin{abstract}
:
Why did Piero Sraffa (1898-1983), one of the most important economists of the twentieth century, make such extensive use of the Saint-Simonian texts, and with what end? And to what extent does Sraffa's evident interest underline the continuing relevance of Saint-Simonianism, including in economics? This paper determines the exact parameters of Sraffa's engagement with Saint-Simon. Two particular moments are identifiable:

- the first comes in the lectures that Sraffa, an Italian emigrant, gave in Cambridge from 1928 to 1931 , authorized and protected by Keynes;

- the second, which is more uncertain as regards the dates, concerns the project to publish the works of Saint-Simon, which seemed to have consumed most of Sraffa's energies from end of the 1950s and into the 1960s.
\end{abstract}

\section{Keywords:}

Sraffa, Saint-Simonianism, continental banking, objectivism

JEL codes:

B10, D63, N00

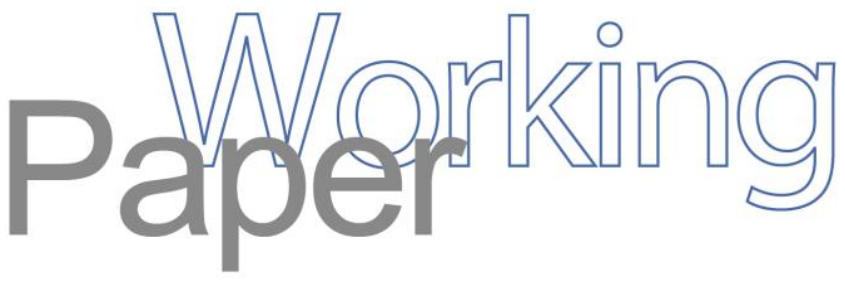




\title{
Piero Sraffa and the project to publish Saint-Simon's works
}

\author{
Michel Bellet and Adrien Lutz ${ }^{1}$
}

Why did Piero Sraffa (1898-1983), one of the most important economists of the twentieth century, make such extensive use of the Saint-Simonian texts, and with what end? And to what extent does Sraffa's evident interest underline the continuing relevance of SaintSimonianism, including in economics? This paper determines the exact parameters of Sraffa's engagement with Saint-Simon. Two particular moments are identifiable:

- the first comes in the lectures that Sraffa, an Italian emigrant, gave in Cambridge from 1928 to 1931, authorized and protected by Keynes;

- the second, which is more uncertain as regards the dates, concerns the project to publish the works of Saint-Simon, which seemed to have consumed most of Sraffa's energies from end of the 1950s and into the 1960s.

JEL classification: B10, D63, N00

Keywords: Sraffa, Saint-Simonianism, continental banking, objectivism

\footnotetext{
${ }^{1}$ Univ Lyon, UJM Saint-Etienne, GATE UMR 5824, F-42023 Saint-Étienne, France. michel.bellet@univ-stetienne.fr

Univ Lyon, UJM Saint-Etienne, GATE UMR 5824, F-42023 Saint-Étienne, France. adrien.lutz@univ-stetienne.fr

This research was supported by the Agence Nationale de Recherche's research program Saint-Simonisme 18-21. We would like to thank Richard Arena, Giancarlo de Vivo, Nerio Naldi and Jean-Pierre Potier for their advice and suggestions. All deficiencies in the text, of course, remain entirely our own responsibility.
} 


\section{Introduction}

Why did Piero Sraffa (1898-1983), one of the most important economists of the twentieth century, make such extensive use of the Saint-Simonian texts, and with what end? And to what extent does Sraffa's evident interest underline the continuing relevance of SaintSimonianism, including in economics? In seeking to answer these questions, we are first called upon to determine the exact parameters of Sraffa's engagement with Saint-Simon, and indeed much remains unknown in this regard. Two particular moments are identifiable, however, which may assist us. The first comes in the lectures that Sraffa, an Italian emigrant, gave in Cambridge from 1928 to 1931, authorized and protected by Keynes; the second, which is more uncertain as regards the dates, concerns the project to publish the works of Saint-Simon, which seemed to have consumed most of Sraffa's energies from end of the 1950 s and into the 1960 s.

On the side of Saint-Simonian studies, Sraffa's interest in Saint-Simonianism is entirely unknown: to underline this point we may review the syntheses of Gentile (1970-1971), Treves (1970, 1973) and especially Manganaro Favaretto (2004), in which, despite an insightful analysis of two centuries of Saint-Simonianism in Italy, Sraffa is entirely absent. On the side of Sraffian studies, the first moment has been clearly identified and analysed: it concerns the monetary writings of the young Sraffa (cf. Panico 1988, 2001, with extensions in 2012 and 2016; De Cecco 2005, 2009, 2013); the second moment is mentioned once by Meldolesi (1982), and then by Steve (2004), on the occasion of their relating personal interviews with Sraffa. These reference, however, have not led to any fuller presentation or analysis. The nature of these two moments is that they can only be accessed and apprehended via a review of Sraffa's Unpublished Papers, ${ }^{2}$ which raises particular issues.

The purpose of this text is first to provide a clear and full presentation of Sraffa's use of SaintSimonianism and, as far as possible, its meaning. The aim, by relying primarily on knowledge of Saint-Simonianism (ANR Saint-Simonisme), is to contribute to engendering the conditions for a re-reading and reactivation of Saint-Simonianism outside its own context. At the same time, we seek also to determine how Sraffa's own uses of the material can shed new light on the meaning of Saint-Simonianism(s), in relation to what has been recorded so far. In

\footnotetext{
${ }^{2}$ On the organization and accessibility of the Unpublished Papers, or Sraffa Papers, see in particular Kurz 1998 and 2009, Garegnani 1998, Smith 1998, Kurz, Pasinetti, and Salvadori 2008, Pasinetti 2001, De Vivo 2001.
} 
addition, this work is part of a renewal of Sraffa's work made possible by the online publication of the Unpublished Papers (Blankenburg, Arena, ands Wilkinson 2012 for a synthesis on this point, as well as Bellofiore and Carter 2018).

In Section I we examine the characteristics of the first moment, and in Section II those of the second, which are more hypothetical. The conclusion will provide an overview of the recurrent events concerning Saint-Simonianism in economics as made visible from the Sraffian perspective, and comment on the redefinition of the vision of so-called utopian socialism, a redefinition in which Sraffa in fact participated, very clearly in the first moment, and more enigmatically in the second.

\section{The first Saint-Simonian moment (1929-1930): the Saint-Simonian bank as a specific institutional innovation and model of "industrial banking" (manuscripts D2/5 and D2/5.6)}

We will briefly review some significant elements in Sraffa's manuscripts. Then the content as well as the status of Sraffa's Saint-Simonian references will be indicated, before drawing up an initial assessment of the Sraffian review.

The collection is comprises manuscripts concerning "Readings on Continental Banking": one central manuscript D2/5, but also D2/6 "I banchieri fiorentini nel 200" (which seems to be related to it, according to Sraffa himself). ${ }^{3}$ D2/5 consists of continuous handwritten course notes (almost exclusively in English), with some references and newspaper clippings, and represents a total of 128 sheets. The course, intended for advanced students (undergraduates) in Cambridge, was held only in 1929 and then in 1930. The other Sraffa course during the period was on "Advanced Theory of Value."

The context of Sraffa's work in this period is as follows. Sraffa was induced to emigrate to England due to the rise of Mussolini, Sraffa's own first texts on Italian banking problems and the monetary policy of power (1922), as well as his early engagement with socialist currents (Gobetti who is Sraffa's cousin, Rosselli, Tasca, and of course his important links and

\footnotetext{
${ }^{3}$ These are Sraffa's notes for a conference scheduled at the Italian Society in Cambridge on 14 May 1929.
} 
collaborations with Gramsci, whom he met in 1919). After a first abortive attempt in 1923, he effected his emigration at the end of 1927. With the direct support of Keynes, whom he had met in 1921 and 1922 during a one-year stay at the LSE, Sraffa obtained a position as a lecturer at the Faculty of Economics and Politics in Cambridge, where he would remain from 1927 to $1965 .{ }^{4}$

The course on the continental banking system ${ }^{5}$ (in which our first moment is situated) came before the publication of Sraffa's pieces on Ricardo and the book he published in 1960, but after several initial texts on money and banking: these include his thesis, written under the supervision of Luigi Einaudi and defended and published in 1920 ("L'inflazione moneteria in Italia"), but also the articles of 1922 published at the request of Keynes, first in the Economic Journal ("The Bank Crisis in Italy"), then in the Manchester Guardian Commercial ("Attuale situazione delle banche italiane" [Italian banking today]). In addition there are manuscripts, a conference paper, and published articles on Italian fascist monetary policy (1923 and 1927) and its effects on income distribution, as well as the Italian translation of Keynes's Tract in 1925. The first discussions with Keynes on the Treatise on Money, with its Wickselian influence, as well as Sraffa's critical comments on Hayek's Prices and Production also began during this period. The course therefore manifests a certain thematic continuity with the first phase of Sraffa's work, focussing as it does on monetary and banking upheavals in the postWorld War I context, notably the 1922 Genoa International Conference. However, it should be noted that the course is also intertwined with Sraffa's developing reflections on the global analysis of the neo-classical economy of Marshall ${ }^{6}$ (see his Italian version of the article on the relations between costs and quantities in a partial equilibrium context, 1925 in Annali di Economia, and his article on the laws of returns, 1926 in the Economic Journal), but also his first reflections on the interest of a return to classical economics and specifically Ricardo

\footnotetext{
${ }^{4}$ Sraffa had held a position at the University of Perugia (1923-1924), and in 1926 became the chair of Economics at the University of Cagliari, before resigning in 1931.

${ }^{5}$ Sraffa rejected Keynes's proposal in 1926 to design a course on value and a course on distribution, but accepted his third proposal for a more applied ("realistic" in Keynes's words) subject matter: Sraffa then proposed a course on value theory divided into two parts, and a "realistic" course on the relations between banking and industry in continental Europe. Finally, Sraffa taught a course entitled "Advanced Theory of Value," held in autumn of 1928 in which he delivered the course we are interested in here (cf. Potier 1991: 35, Marcuzzo 2005).

${ }^{6}$ Perhaps Sraffa was unaware of the socialist influence on the young Marshall in the 1860s and early 1870s (before Economics of Industry), before he turned away from it. And perhaps Sraffa did not know of Marshall's Lectures on Socialism and the functions of Government (June 1886), which deals with Saint-Simon at certain points.
} 
(Potier 1991, Signorino 2005), on which he began serious work in early 1930. ${ }^{7}$ This work of criticizing marginalist economics and renewing economic theory from the perspective of classical economics has sometimes been interpreted as a break in his work as a whole, ${ }^{8}$ but the publication of Unpublished Papers has opened up new perspectives on this phase, and reinforced the need for a broader interpretation. For instance, Panico (2001) and De Cecco (2013), relying in particular on the 1929-30 Continental Banking manuscript, made a major contribution to situating Sraffa's perspective and linking it to the more general work on monetary policy and banking systems.

It is important to give a fuller and more precise account here in order to bring out the relationship to Saint-Simonianism. The Continental Banking manuscript focuses on a particular theme: "continental banking," also known as "industrial banking," its emergence, structure and success. The aim is to show that continental banks are less specialized than Anglo-Saxon banks, which traditionally collect and manage deposits, issue cheques payable on demand related to these deposits, discount negotiable instruments, issue bank drafts and provide short-term credit. For the Continental Bank, this type of activity, essentially conceived as an extension of trading, is only a part: instead, its role is mainly to finance the fixed capital of firms and to take stakes in them, in order to become their permanent partners. German banks are the most representative of this system, which had according to Sraffa been developing for half a century, but industrial banks were actually born in France, although it was in Germany that they became prosperous: strictly German banking techniques were then developed and then (re)applied in other countries (p. 1). It is therefore as regards the origin of these industrial banks, which are engaged in financing and controlling business, that Sraffa refers to the Saint-Simonians who, at the beginning of the nineteenth century, broke with the prevailing notions of banking (joint stock banking). The first bank of this type for Sraffa was Crédit Mobilier, created in 1852 in Paris by the Pereire brothers and forced into bankruptcy in 1867 after a crisis. Sraffa refers to Crédit Mobilier by situating this type of banking project within a "utopian scheme of social reform [...] the Pereires were disciples of Saint-Simon, the socialist and they drew from his doctrine not only the general idea, but actually the technical scheme which their bank was based" (p. 8). On this point, Sraffa mistakenly refers to SaintSimon and attributes to him an extract written in fact by his disciples (p. 9). Moreover, by this

\footnotetext{
${ }^{7}$ It was in 1930 that Sraffa officially became the editor of Ricardo's writings.

${ }^{8}$ The course "Advanced Theory of Value" has received much more attention than the "realistic" course examined here.
} 
date Sraffa may not have actually read Saint-Simon. ${ }^{9}$ Sraffa also assimilates the disciples several times to the master.

Despite this mistake, Sraffa refers very precisely to the doctrinal work of the disciples as set out in their essential common work, The Doctrine of Saint-Simon: An Exposition [DSS]. DSS gathers together a series of public sessions in 1828-29, prepared collectively, and published in three editions from 1830 (another series of public sessions cover 1829-1830, although Sraffa limits his references to the first years only). ${ }^{10}$ This corpus is the main collective reference of Saint-Simonianism after Saint-Simon: it was developed after the death of the master (1825) at a time when the collective doctrinal elaboration of the disciples of SaintSimon was in full development (just before and after the July Revolution in 1830). Sraffa gives long quotations in French of the 7 th session of this 1 st year. ${ }^{11}$ This session (“Constitution de la propriété. Organisation des banques"), after developing an account of ownership as a social function, not as an extension of an individual right of appropriation of things, then leads on to the organizing and enlightened role of banks, contrasted with the isolationism of individualist strategies. It capitalizes on the previous work of Enfantin, Rodrigues and G. D'Eichthal ${ }^{12}$ on the banking system in the Saint-Simonian newspapers Le Producteur, Le Globe and other works. ${ }^{13}$ Sraffa therefore studied DSS, and particularly the session on "the industry of banking" (p. 9), ${ }^{14}$ and read out to his students the significant excerpts he chose to copy (comprising five pages, himself underlining several sentences and

\footnotetext{
${ }^{9}$ On the role of banks in Saint-Simon, see Yonnet 1998. Concerning the disciples' conceptions of banking, see Barbaroux and Lutz 2018, and in particular Jacoud 2010, 2012.

${ }^{10}$ The second year covers the oral sessions from November 1829 to June 1830, published in two editions in 1831 and 1831-1832. These sessions have acquired a reputation for being strongly religious in tone, which has often led them to be excluded from the "socialist" and sometimes "republican" framework that would quickly become attached to Saint-Simonianism, at least in France. Moreover, the term "bank" no longer appears in it.

${ }^{11}$ The passages quoted (9-10) cover DSS: 259-261, 267, and 273 of the 3rd edition. The pagination indicates that Sraffa used this edition published in August 1831, which was reproduced in 1924 with the introduction and scientific notes of Bouglé and Halévy. However, Sraffa does not seem to have used this reprint, which is still a reference (regarding the first year of the sessions). Nevertheless, it is this edition that he will later buy, and that we will find in his library (cf. part II).

${ }^{12}$ Adolphe d'Eichthal (1804-86), a banker linked with his brother Gustave to the disciples of Saint-Simon, also participated in the Crédit Mobilier, of which he was vice-president in 1854.

${ }^{13}$ Other references, however decisive, are not taken into account by Sraffa: in particular Enfantin's Économie politique et politique (1831), Isaac Pereire's Leçons sur l'industrie et les finances, prononcées à la salle de l'Athénée, suivie d'un projet de banque (1832) (by his brother Emile Pereire), and also brochures from previous articles in Le Globe, a newspaper that became Saint-Simonian after the 1830 revolution in France. The banking project presented in September 1830, with its characteristics (issuance of interest-bearing bonds to holders etc.) is particularly noteworthy. Debates between Gustave D'Eichthal and Sismondi on public credit are also an important piece (see Lettres à MM. les deputes composant la commission du budget sur la permanence du système de crédit public, 1829, and Sismondi's reply, 1829, Lettre à G. D'Eichthal, July 19, Bibliothèque Arsenal, Fonds d'Eichthal, MS 13747, R 55111).

${ }^{14}$ This expression is Sraffa's translation into English of the expression "l'industrie des banquiers" used by the Saint-Simonians on the page cited by Sraffa (DSS: 267).
} 
expressions). His presentation accurately recalls the Saint-Simonian global project of a nonrisky, limited (according to capacity), and coherent coordination of production, and describes the hierarchical banking system desired by the Saint-Simonians in 1829, with a centralized bank allocating to producers the entire production fund (instruments, land, labor, etc.) through specialized second-order banks, at the industrial and territorial level. The central bank then becomes the government in the material order, allowing a harmonious, non-anarchical organization of production. ${ }^{15}$

After this rather informed resumé of the Saint-Simonian doctrinal basis, Sraffa introduces the case of the Crédit Mobilier, created little more than twenty years later in the context no longer of the Restoration and Louis-Philippe, nor of 1848, but now of the Second Empire. This case is therefore presented in the course as being directly inspired by the Doctrine. The creation of this bank by the Pereire brothers, ${ }^{16}$ and a synoptic history up until its failure, is supported by a long extract from the book by the banker Jacob Riesser (1905), as well as significant extracts from the writings of Maffeo Pantaleoni (1895), professor of economics and one of the founders of marginalism and pure economics in Italy, taken from the first of three long articles of 1895 devoted entirely to the fall of the Société générale de crédit mobilier italien et la compagnie immobilière in $1893 .{ }^{17}$ In addition, various recent and less recent authors, bankers or academics are referenced and, as we will see, used either in the presentation and analysis of the case of Crédit Mobilier, or in the more general and current scope of the banking organizations of interest to Sraffa: from France, M. Aycard, Edmond Baldy, and Georges Le Montréer; from England, Richard Tooke and William Newmarch, Philip Barret Whale, Walter Leaf (with extracts), and Herbert Somerton Foxwell ${ }^{18}$ (with extracts); from the

\footnotetext{
${ }^{15}$ In the Saint-Simonian scheme, the bank is the physiological transposition of the nervous system (brain and nerves) into the organized social body; the influence of physicians on the doctrine (Bichat, Cabanis and Buchez in particular) was powerful.

${ }^{16}$ Émile Pereire (1800-1875) and Isaac Pereire (1806-80) were two brothers from a Portuguese Jewish family who settled in Spain and then in France in the middle of the 18th century, in Bordeaux. They moved to Paris in 1822 and 1823 respectively. One of the first disciples of Saint-Simon, Olinde Rodrigues, also linked to the banking world, and brother-in-law of the Pereire family, introduced them to the doctrine of Saint-Simon in 1825. On the Pereires, see Guéroult 1956, Autin 1984 and Davies 2015.

${ }^{17}$ April Issue: 90-93 and 400. Sraffa uses the selection of articles published in book form in 1911. Pantaleoni died in October 1924: it should be recalled that it was Sraffa who wrote his "obituary" published in December of the same year in the Economic Journal. (See also Unpublished Papers D3/4; it notes "during this period, having acted as liquidator of a large joint-stock bank, he was able to write his monograph on 'La caduta del Credito Mobiliare,' which is still unequalled as an analysis of the continental type of banque d'affaires, a veritable masterpiece comparable in some respects to Bagehot 'Lombard Street'" (Manuscript typed in D3/4: 1-2; Sraffa underlines).

${ }^{18}$ Sraffa attended Foxwell's courses when he was enrolled as a research student at the LSE in 1921 and 1922, and Foxwell corresponded with him in 1923, to support him in a position as an assistant in economics at the Genoa Business School (Naldi 2009).
} 
United States, Henry Parker Willis and Benjamin Haggot Beckart; and from Germany, Otto Jeidels, Adolf Weber, Arnold Fendler, and Raimund William Goldschmidt.

Sraffa presents Crédit Mobilier as an attempt to set up what could provisionally be seen as an anticipation of a banking system different from the English system, on the basis of a realistic socialist utopia. At the same time, according to Sraffa, this institutional innovation did not emerge from the usual channels ${ }^{19}$, but rather appears to be spontaneous, gradually established without conscious intent; and its effects are manifest only ex post, as in the case of the innovation of the cheque, which was developed, without any initial intention, to circumvent the limitations on the issuance of banknotes in Great Britain (Peel's Bank Act of 1844). In the case of industrial banking, this continental institutional innovation was initially part of a conscious, pre-established plan (the Saint-Simonian reform plan) followed by a breakthrough. This system was then fully developed in Germany at the end of the nineteenth and beginning of the twentieth centuries. This system has had several names: "industrial bank" (the term used by Sraffa), "merchant bank," "investment bank," "credit bank," "effektenbanken” (or securities banks), "speculative bank," "universal bank," "mixed bank," etc. These terms appear in the works used by Sraffa.

In his notes, Sraffa points out that Crédit Mobilier was created in 1852, based on a principle which was certainly not concerned just with providing short-term financing for companies, like usual banks, but rather of taking equity stakes for long-term fixed capital financing. A wider goal was to centralize the financing of these companies by replacing the initial securities with bonds issued by Crédit Mobilier, thus making it possible to finance the economy through a better distribution of savings. The Saint-Simonian hypothesis of a single French company was in fact a key element of the Crédit Mobilier programme, and had international ramifications (including a project to issue a European credit security). This transformation of financing had to correspond to the scale of the economic transformation at stake (transport, industry, etc.), and went beyond the traditional means of the deposit bank. It was also based on a growing dynamic of financing and investment. The original scheme was, according to Sraffa, to access resources for investment, partly from the bank's own capital shares, and partly through issuances of bonds earning fixed interest; the amount of bonds issued at different periods was assumed to correspond to the investment amounts of the

\footnotetext{
${ }^{19}$ Sraffa used the expression "amazing change" several times to describe the emergence of this new institution, i.e. the industrial bank.
} 
various liquid assets, so that there would be an almost strict correspondence between the quality of assets and that of liabilities. As Pantaleoni writes (quoted by Sraffa on p. 6), these obligations were to be the pump as well as the channel of communication between Crédit Mobilier and the capital market, taking on the function that deposits have in other banks. The securities were eventually even to be used as currency, in the minds of the Pereire brothers, being preferable to notes because they brought interest. According to Sraffa, the functioning of the bank is not to be questioned. Moreover, like Riesser's opinion, Sraffa emphasizes the role that this institution played in the country's economic development (railway development in particular). He puts forward three main causes, which intersect to a very large extent with Baldy's analysis (p. 7 to 9 in particular) as well as Riesser's: the blocking by Napoleon III's government of the issue of bonds, for fear that the bank's growth will turn it into a more influential power than the government itself. Consequently, Crédit Mobilier was obliged to link its shares solely to its own capital and, to do so, had to invest new shares and excessively boost its dividends, including by artificial means. The second cause was the use of deposits to buy securities; and the third concerns the hostility of the Banque de France.

In his analysis of this specifically continental institution of industrial banking, launched by the experience of Crédit Mobilier, Sraffa assigns particular importance to the question of asset liquidity for an industrial bank (six pages are devoted to the question). This issue seems particularly sensitive for a bank like Crédit Mobilier, unlike banks that have deposits and make short-term loans. However, Sraffa insists on the idea that the liquidity of assets actually depends more on the difficulty of selling them at current prices (and therefore on their access to an active market with a powerful buyer, namely the central bank - which makes them "marketable"), than on their maturity (i.e. their being "payable at an early date," p. 11). Various assets and commodities can therefore be ordered according to their liquidity. If the active market exists, the solvency of the institutions using it is made easier (the bank finds liquidity immediately). Thus, it is the quality of the institutional relationship between the central bank and its partners that is important (and generally speaking this relationship is more cooperative and less constrained in the continental system than in the English). ${ }^{20}$

Sraffa then turns to Germany, to describe the continuation of the industrial banking model:

\footnotetext{
${ }^{20}$ Sraffa notes that this is also true for the goods market $(11-11$ bis $)$ and the size of the bank does not matter: "liquidity is different for different quantities of the same security or commodity," and a distinction must be made between risk and liquidity.
} 
this constitutes the major part of the course, covering first the period 1870-1914, and then the period after the war. Regarding the first period, Sraffa points out that the unit opened in Germany by the Zollverein in 1851 made commercial and industrial demands that had to be supported financially: "banks of a new type" are then established, which reproduce the SaintSimonian scheme of Credit Mobilier: four in particular, including Darmstädter Bank, created only one year after Crédit Mobilier and under the direct influence of its organization (Abraham Oppenheim of Cologne, who was one of the founders of Crédit Mobilier, was a cofounder of this bank). ${ }^{21}$ The rest of the manuscript covers the period 1871-1914, again for the German case, and indicates that the institutional characteristics of the banking system of the previous period were maintained without significant change. ${ }^{22}$ For the post-war period (which was marked by the loss of sovereignty of Germany, and brought major changes), the Saint-Simonian reference is no longer directly manifest in the Sraffa manuscript (except for a page, probably misplaced, concerning a reference to Tooke and Newmarch on Crédit Foncier and Crédit Mobilier); ${ }^{23}$ instead, there are only several references to the general link between industrial banking and the importance of the concentration and rationalization of banks in the economy. The topics covered (concentration, degree of control by the central bank, problems posed by hyperinflation) are in fact included in the history which Sraffa presents concerning the establishment and development of industrial banking in Germany.

What conclusions can we draw at this early stage from Sraffa's use of Saint-Simonianism? First of all, it should be pointed out that the two dimensions of Sraffa's thesis, namely the Saint-Simonian Crédit Mobilier as an antecedent of industrial banking, and industrial banking as a type (or ideal-type) of a continental banking system differing from the English system, are not insights that are strictly specific to Sraffa. Indeed, on both of these dimensions Sraffa makes many borrowings; in particular, Baldy (1922) and especially Riesser (1905) put forward the same interpretation. Baldy's $\mathrm{PhD}$ thesis ${ }^{24}$ contains the central argument that the first merchant bank in France was linked to the Saint-Simonian project and the Crédit

\footnotetext{
${ }^{21}$ Sraffa could also have pointed out that Oppenheim's sister was married to Benoit Fould, one of the founders of the Crédit Mobilier, and very close to Napoleon III. Similarly, he could have pointed out that Gustav Mevissen, who attempted a universal banking project in Germany, was a reader of Saint-Simon and had contacts in Paris with Saint-Simonians.

${ }^{22}$ On these points, see De Cecco 2005: 355-58.

${ }^{23}$ See: 51 . It is this position that probably explains why Sraffa's reference to an author as important as Tooke (on Crédit Mobilier) was not evoked by Continental Banking's commentators.

${ }^{24}$ Baldy's PhD thesis jury was chaired by Charles Rist, who played an important role in the French monetary conceptions of the interwar period (he was Deputy Governor of the Banque de France). An important development on the Saint-Simonian bank and the experience of Crédit Mobilier can be found in this author's 1938 book on the history of credit.
} 
Mobilier. This thesis refers to Crédit Mobilier only in the introduction, but the idea is very clear, including as regards certain techniques such as the substitution of securities later practised by German investment banks:

These are exactly the ideas of Saint-Simon and the Pereire brothers that we recalled in our introduction: as in many fields, it must be noted that it is French people who were the promoters of these ideas who came back to us today from Germany with an appearance of innovation (Baldy 1922: 117). ${ }^{25}$

All of Part II of Riesser's book is devoted to Crédit Mobilier, with "its merits and faults," and as having influenced German banks. ${ }^{26}$ As in Sraffa's course notes, there is also a reference to Zola and his novel L'Argent as having been inspired by the emblematic experience of the Crédit Mobilier.

Similarly, Barret Whale (1930), who is referenced by Sraffa, also describes a continental model of less specialized banks, stating in his introduction: "the earliest examples of the Continental type of bank may perhaps be found in the Belgian Société Générale established in 1822, and the more famous Crédit Mobilier of France, established in 1852" (Whale 1930: 2). His chapter one also recalls that the establishment of the "Creditbank" followed the model of Crédit Mobilier, in particular through the creation by the Pereire brothers of the Darmstädter Bank. One can also find an interpretation of this type in Adolf Weber (1922), also referenced by Sraffa. ${ }^{27}$

On the specific presentation of the Crédit Mobilier experience and the lessons to be drawn from it, Sraffa uses several otherwise familiar elements in a rather specific way. He draws factual elements from Aycard (1867), but adopts a very critical stance on them: ${ }^{28}$ just like

\footnotetext{
25 "These are exactly the ideas of Saint-Simon and the Pereire brothers that we recalled in our introduction: as in many fields, it must be noted that it is French people who have been the promoters of these ideas that come back to us today from Germany with an appearance of novelty." (We translate).

${ }^{26}$ Riesser was a member of the management committee of Darmstädter Bank, a type of bank inspired, as shown above, by the Crédit Mobilier, and in general he defends what he calls the "universal bank."

${ }^{27}$ Sraffa's other references, in particular to German banks, do not include any mention of the Pereire brothers' Saint-Simonianism and Crédit Mobilier. See for example, Georges Le Montréer's book, often cited by Sraffa, $L a$ rationalisation des banques allemandes (1928), or Herbert Somerton Foxwell's renowned Papers on current finance (1919). However, this absence of a link remains quite rare in the specialised banking literature of the time. Interesting enough, a dispute occurred related to the link between Crédit Mobilier and the organization of the German bank in modern historiography (see, for example, several works by Richard H. Tilly in the 1980s).

${ }^{28}$ Sraffa rightly notes that Aycard is a small Parisian banker fearing the influence of Crédit Mobilier.
} 
Riesser, for whom Aycard's text is nothing more than a pamphlet. The loans from Pantaleoni (1895) concern more certain descriptive aspects of the Pereire programme and the statutes of Crédit Mobilier, as well as certain management errors that are highlighted by Pantaleoni's global approach. Moreover, Pantaleoni's perspective is marked by a much more general questioning of the legitimacy of a rescue by the Central Bank and the State in the event of bankruptcy. Concerning Tooke and Newmarch's book (1857), it had not been sufficiently noticed that in the sixth part of their book, dedicated to the French situation, the authors devoted six sections (24-29) to Crédit Mobilier as well as three to Crédit Foncier: in a brief comment, Sraffa refers to these 40 pages as "excellent." 29 These sections of Tooke and Newmarch's book contain a very precise presentation of Crédit Mobilier's statutes and programme, the most important and most audacious of which was, for the two authors (1857: 114), the creation of long-term bonds. As we noted above, Sraffa emphasizes the centrality of this aspect. We may therefore ask whether, in all the various and numerous borrowings Sraffa makes in order to sustain his central thesis, he remains wedded to his Saint-Simonian reference point, and is he true to the scope he assigns to it? In our opinion we can respond positively; five observations in particular support this conclusion.

First of all, the Saint-Simonian reference in Continental Banking is not limited to mentioning the well-known case of Crédit Mobilier (a typical example of what is called "practical SaintSimonianism" and the promotion of the bank/industry relationship). Sraffa insists, much more than the others do, on the overall framework of the Saint-Simonian doctrine that inspired the Pereire initiative, and adduces long extracts to this effect. Quite apart from the respectable level of knowledge he displays of certain Saint-Simonian texts (and this despite significant deficiencies regarding certain Saint-Simonian texts specifically on the issue of banking), we will see that this concern is not the result of chance. Nevertheless, it remains unclear how Sraffa acquired his knowledge of Saint-Simonianism prior to his exile from Italy, even though the doctrine has indeed had a particular resonance in his home country (see Faucci and Rancan 2009 in particular). Despite the significant work of Manganaro Favaretto (2004), the status of social reformers or utopian socialism, to which category Saint-Simonianism is generally associated, has yet to be clarified for the period of the late nineteenth and early twentieth centuries, and especially within the cultural atmosphere of Turin. Although the importance of some of Sraffa's socialist-oriented mentors (in high school Domenico Re, and

\footnotetext{
29 "Ottimi capitoli sul Credit Mobilier e sul Crédit foncier in Francia e Germania" (D2/5: 51).
} 
then Umberto Cosmo who later introduced Sraffa to Gramsci) is not in dispute, it remains unclear whether "Saint-Simonian socialism" was part of these intellectuals' ideals. It is possible, however, to examine at least partially the way in which Saint-Simonianism was presented during his studied at the University of Turin from 1916. Beyond the elements and traces that we have collected here, there is a need to examine more precisely and systematically the possible influence of Achille Loria (whom Einaudi called the "Italian Marx"), ${ }^{30}$ Luigi Einaudi (in his classes but also through the texts of the Social Riforma, a journal launched in 1894 of which he was editor after 1896, then co-owner and editor), ${ }^{31}$ Gioele Solari (mainly in philosophy of law), ${ }^{32}$ and Gaetano Mosca (in political science) (see on some of these points Potier 1991, D’Orsi 2001, Naldi 2009). ${ }^{33}$ Gramsci (1929-1932) also

\footnotetext{
${ }^{30}$ Loria (1857-1943), in his Corso completo di economia politica (1910), makes room for Saint-Simon in the analysis of the historical development of political economy, as "the first socialist writer in modern times," but "without scientific or positive content" (1910: 108-9). The presentations of Fourier, Owen and Blanc follow that of Saint-Simon. But, above all, in Book IV, Chapter XV (L'organizzazione del credito), Loria returns to the fall of Crédit Mobilier in France (1910: 557-59), emphasising its negative aspect and the need to respect the specialization of banks. It should also be noted that Paul Lafargue's text on La propriété. Origine et evolution (1890), whose Italian translation was preceded by a substantial critical introduction written by Loria (1896), contains in part 6 on "capitalist finance" a presentation of the experience of Crédit Mobilier and the banking approach of Saint-Simon and Enfantin (1896: 356-60). Despite his reserved opinion on Loria, given the needs of his training in Turin and also his political commitments, Sraffa was familiar with these texts (Loria was also known for his criticism of Marx's theory of value in 1901 and his de facto participation in a so-called revisionist movement on the "Marxism crisis").

${ }^{31}$ Einaudi (1874-1961) played a major role in Turin and Italy. Although he was not Sraffa's direct teacher in financial science (despite his famous course), he was the rapporteur of his $\mathrm{PhD}$ thesis. Einaudi discussed monetary issues and policy with Sraffa (mostly in 1927). He was also known for his monographs on economic history and his texts on the history of economic thought. His references to Saint-Simonianism are very limited. When he speaks of the cooperative movement, he shows more sympathy for the Fourierist utopia than for that of Saint-Simon, which he saw as a centralizing and planning precursor of socialism. It should be noted, however, that the title of one of his articles of January 1919, published in the Rivista d'Italia, uses the famous SaintSimonian notion of the "government of things." Regarding La Riforma sociale, which quickly became the voice of the Laboratorio d'economia politica di Turino, in which Einaudi also played an essential role, two notable articles were published in the period: an article in Italian by G. Weill (1894), an historian and French interpreter of Saint-Simonianism, on the origins of the doctrine of Saint-Simon; and an article by Bernardo Mosca (1921), the son of Gaetano Mosca (see below) on the perception of Saint-Simon's thought over the last century. Here again, one can think that, given the role of Einaudi in Turin, the links with Sraffa's father and Sraffa's assiduous and brilliant work during his training, all these elements were known to him.

${ }^{32}$ Solari (1872-1952) was in Turin from 1918. He attached great importance to Auguste Comte's positivism and to questioning the crisis of individualism in philosophy of law. He directed Renato Treves's PhD thesis on SaintSimonianism in Turin (published in 1931).

${ }^{33}$ G. Mosca (1858-1941) was a member of Sraffa's PhD committee. Sraffa clearly read and worked on the Elementi di Scienza politica (1896, revised and expanded in 1923) as part of his training. Mosca is often considered as the founder of political science in Italy. He underlines three decisive points of Saint-Simonianism in political theory:

- A theory of the political class which is not built on the examination of forms of government (democratic, monarchical etc.), but on the effective modes of exercise of power;

- The role recognised to a part of society prefiguring the theory of elites;

- The hypothesis that the ideally organized State is based on an absolute correspondence between services rendered by the individual to society and the rank he is led to occupy (theory of capacities and works).

With Comte as his secretary, Saint-Simon is considered as highly important, and as situated in the line of Machiavelli, Marx and Engels, Gumplowicz and Michels (Mosca 1923, 446, 526 to 530, 535-537, 666, 726). Mosca's student Federici published a book on Saint-Simon in 1922, prefaced by Mosca in the same vein. It is
} 
read the Saint-Simonians, as evidenced by his Prison Notebooks.

Sraffa thus deployed Saint-Simonian ideas in the resolution of a problem that was quite commonly discussed at the time, but to which he gave a very particular orientation. The basic problem is the creation of a new type of bank to finance industry and, more broadly, a banking system with features and constraints differing from the English system. Sraffa was involved in the rise of the debate on finance and banking in economics in the years 1910 and 1920, and did a lot of work on the role of the German bank, and the Crédit Mobilier of the Pereire brothers - often presented as an anticipation of the German model, as we have noted. However, Sraffa uses this framework to examine the emergence of institutional innovation and its characteristics. As we have seen, this case illustrates two different different modes of institutional emergence, one characterized by a long and non-voluntary process (the usual English case), the other representing a more marked change and resulting from a voluntary plan (the case of Crédit immobilier, resulting from a previous Saint-Simonian plan, and being for Sraffa typical of the so-called continental system). Even though Sraffa undoubtedly underestimates the close ties forged by the Pereire family with Louis Napoleon before and just after the 1851 coup d'état, and the interest Napoleon had from the outset in the creation of Crédit Mobilier against the private Rothschild banks and their links with Bourbons, ${ }^{34}$ Sraffa aims to highlight the emergence of a new banking organization. This specific line of questioning, which leads him to defend the realistic possibility of a utopia by embedding it in an institutional problem, reflects Sraffa's interest in institutional issues, historical formation, and the role of conventions or rules in organizing interest groups and the State. These agreements, which are here linked to money no longer seen a simple means of exchange, and hence linked to banking, are decisive because they modify the distribution of income and contribute to the determination of the level of equilibrium (Panico 2001). We may pick out several points for amplification.

(i) Sraffa's analysis of the continental banking system shows the importance he assigns to central issues of monetary theory. The course is therefore not only a course on concrete and practical economic issues (i.e. "realistic"): it also has a theoretical content. This is the case, as we have seen, with regard to the treatment and definition of liquidity. It should then be noted

among Mosca and his entourage that we find the most important and systematic references to Saint-Simon, and these may have influenced Sraffa in his scholarship.

${ }^{34}$ On the links between the Pereire brothers and Napoléon III, see Davies 2015, especially: 107-17. 
that this question probably arose in discussions between Keynes and Sraffa, with a possible financial motive in future prospect (Keynes in his Treatise, 1930, and in some later texts, perhaps influenced by Sraffa, as noted by De Cecco 2005, 2013). ${ }^{35}$ Note also, however, that Sraffa does not make the link with certain earlier texts by Enfantin, Rodrigues and Pereire, concerning the defence of the principle of the system of Law, the general need for fluidity within the social workshop promoted by a central bank, which involve changes in the relationships between social categories (for example, movable and immovable property, as well as the transition between idle and working people), and also concerning the role of credit securities and bonds (Pereire 1831, 1832) in this fluidity. ${ }^{36}$ As already noted, the link with the theory is also found in the assumption that wage levels can be influenced by monetary variables and central bank policy, and thus by institutional or conventional configurations: the interest rate itself is an unnatural but conventional variable. On this point therefore the course also displays a link to the Sraffian critique (1932) of Hayek's Price and Production and the ensuing debate. In a very different context, Isaac Pereire presents this hypothesis of a conventional construction of value and interest rate in his Cours à l'Athénée (1831, 2nd lesson in particular, on the "political" character of these concepts, i.e. their dependence on a social mode of distribution and remuneration).

(ii) The lesson from the role of the Saint-Simonian doctrine, but also of Crédit Mobilier, is fundamentally positive for Sraffa, despite the bankruptcy of 1867; he therefore differs from many of the usual assessments at the time (in particular in France, by bankers or the authorities, with the usual and repeated reference to Aycard). ${ }^{37}$ This means that the principle of Crédit Mobilier is, as we have seen, to be defended, but only within the framework of a particular conception of institutional legitimacy and coherence. It does not seem to us that Sraffa wants to defend the Saint-Simonian experience of Crédit Mobilier, and the German banks inspired by this system, in the name of absolute superior efficiency in global economic

\footnotetext{
${ }^{35}$ Kurz wrote: "In this context it is worth mentioning, as de Cecco (2005) pointed out, that in his lectures on continental banking, which Sraffa gave to third year undergraduates in Cambridge in the springs of 1929 and 1930, he introduced the idea that different assets and commodities may be arranged in order of liquidity. According to de Cecco, Keynes in his theory of liquidity preference was in all probability influenced by Sraffa's respective argument, which can be traced back to Sraffa's studies of "forward exchange rates, around 1919, and provided Keynes with data on the lira's forward rates"; see de Cecco in Kurz, Pasinetti, and Salvadori 2008: 190. ${ }^{36}$ On some of these points, see Barbaroux and Lutz 2018 and Jacoud 2010, 2017, already mentioned. It should be noted that fluidity is one of the two characteristics of physical bodies in Saint-Simon (cf. below part II).

${ }^{37}$ Pantaleoni (1895) also remains on the negative side. One of the few defences of the experience of the Crédit Mobilier can be found in Johann Plenge's thesis (1903), in the name of the "universal bank." Sraffa does not quote this book. Vergeot's more general thesis (1918) is also not cited. Despite the limited hindsight, Tooke and Newmarch (1857), in their in-depth analysis, are very negative about the fatal logic of a credit paper not subject to a quantitative limit, which is induced, according to them, by the Pereire project (see sections 25 and 26).
} 
development - a debate that has continued ever since, including up to today (see recent comparative economic analysis of Crédit Mobilier in Paulet 1999 and Marguerat 2015 with their comparative analyses of the French, German, and English banking systems). ${ }^{38}$ According to Sraffa, the key issue is rather of showing the possible different institutions which historically have emerged in forms that are specific to a given moment (for example, the Saint-Simonian voluntary plan) and which have worked. These successful forms can be transposed spatially (here, France-Germany) and temporally (from the Saint-Simonian plan from the 1830 s to the 1860 s and then to 1914), provided that institutional coherence is respected and maintained (the question of defining liquidity, for example, is part of this coherence).

From this point of view, the Continental Banking manuscript emphasizes history (and not only the history of economic thought), ${ }^{39}$ in order to understand differences in attitudes, and ultimately differences in institutional systems. It is therefore not simply a question of emphasizing that the Saint-Simonian bank more or less clumsily anticipated the future. ${ }^{40}$ For Sraffa, from 1850-1870 the conditions for the success of Crédit Mobilier were present (in particular the demand for capital, lack of investors). The causes of failure are therefore not related to the time lag: the scheme, as presented in his course, was valid in itself, practicable, and successful (p. 4). For Sraffa there is therefore a twentieth-century relevance for SaintSimonianism, manifest in the scheme of industrial banking, and Sraffa tries to give a precise status to this relevance. The underlying subject of the Continental Banking course, in our opinion, is the following: the birth and development of an institutional innovation giving rise to the implementation of a specific financing system, by stabilized agreements, differing from other systems (in this case the English). Again in our opinion, the employment of SaintSimonianism in Sraffa's manuscript makes sense in this context.

(iii) Finally, it should be noted that, given what we will discuss in the second part of our text,

\footnotetext{
${ }^{38}$ We will not here make reference to the substantial work by historians on the Crédit Mobilier, starting from Cameron's founding article in 1953, and including Gille, Landes, Gerschenkron, Confalonieri, Ratcliffe, Stoskopf and others. We limit ourselves to mentioning only two assessments that help to situate Sraffa's earlier work: "In final summary, the Credit Mobilier was a potent force for economic development in the environment in which it existed. Its direct and immediate contributions to the mise en valeur of Europe were considerable; but the indirect and intangible results of its activities were of greater importance and more lasting benefit" (Cameron 1953: 488); "It was the great eruptive effect of the Pereires that profoundly influenced the history of Continental banking in Europe from the second half of the past century onward" (Gerschenkron, 1962: 11).

${ }^{39}$ From a technical point of view, if we look at the balance sheets, for Sraffa there are few differences between the English and German banks: "Difference chiefly in attitudes, due to traditions. Hence, necessity of history," Sraffa writes on a single sheet of notes (not paginated in the manuscript).

${ }_{40}$ Anticipation, in the sense of unrealistic conditions, is better represented by the Belgian credit of the 1920s. The term is therefore inappropriate for the Saint-Simonian bank.
} 
Sraffa does not seem to strictly follow Marx's point of view regarding the Saint-Simonian bank. In Book III of Capital, in the version composed and edited by Engels (1894), which Sraffa read in its original version, the references to Saint-Simonianism are terse/concise, and all concern the Pereire brothers and Crédit Mobilier (chap. XXVII, Sharing profit in interest and corporate profit; and chap. XXXVI, "Pre-capitalist conditions"). The same is true in the History of Economic Doctrines (sometimes presented as Book IV of Capital, prepared by Kautsky), which Sraffa also read in $1927^{41}$ in the French version (Annexes on income and its sources, the vulgar economy, concerning interest-bearing capital). In both texts, Marx calls into question an approach that, by focusing on credit, puts interest-bearing capital at the heart of the analysis, and thus only the distribution of profit among categories of capitalists. His target was primarily the Proudhonist theses on free credit, but Saint-Simonianism was also at issue. However, Marx underlines the dual aspect of the credit system: the development of capitalist production, and the transition to another mode of production. ${ }^{42}$ Sraffa was certainly not able to read Marx's six articles published in the New York Daily Tribune in 1856 and $1857,{ }^{43}$ all devoted to Crédit Mobilier, and much more precise on the Pereire project and the analysis of the bank's evolution: according to Marx, despite its Saint-Simonian dressing, because of the gap between the amount of its capital and the operations it carried out, the institution could not avoid bankruptcy. Sraffa agrees with Marx on one point: that Crédit Mobilier was very much a project of its time-for Marx, the lack of capital and the weakness of the French banking system was what made it possible for the Pereire brothers' project to succeed. ${ }^{44}$ But it should be noted, first, that Sraffa does not engage in any theoretical debate on money capital and the notion of financial capital, even though Hilferding (1910) briefly but directly mentions Pereire. ${ }^{45}$ Sraffa, in what is admittedly a course for students, here sets aside an important Marxist issue. Moreover, Sraffa does not reduce his analysis to highlighting a collusion of interests between the bank and the political authorities. As we have seen, Sraffa uses the experience of Crédit Mobilier to highlight the importance of specific

\footnotetext{
${ }^{41}$ See Part II, on Sraffa's subsequent insistence on publishing an Italian edition.

42 "It is this ambiguous nature, which endows the principal spokesmen of credit from Law to Isaac Péreire with the pleasant character mixture of swindler and prophet" (Marx, Capital, Book III, part V, 28: 318). Marx had planned to develop his ideas on credit in Capital, but was unable to achieve this.

${ }^{43}$ The manuscript of the Sraffa Unpublished Papers H3/26 is evidence of his reading of Marx's articles in the New York Daily Tribune, or at least bibliographic research upon them. However the manuscript dates from 1960. Sraffa bought in 1961 a run of this newspaper.

${ }_{44}$ "This form, incidentally, could become dominant only in a country like France, where neither the credit system nor large-scale industry had reached the modern level of development" (Marx, Capital, section VI, 36: 451).

45 "The original pioneers of credit were the romanticists of capitalism like Law and Pereire..." (Hilferding, 1910, Finance Capital, chap.10, last sentence ).
} 
institutional mechanisms (relationship between central banks and other banks, and between banks and companies) and therefore of administrative and political interests that are partly autonomous. Thus, the 1929-30 course includes a development of the reading that Sraffa had already engaged upon in his critical correspondence with the Marxist Tasca in 1927 concerning the interpretation of fascist monetary policy (Panico 2001). We could, therefore, in this first moment, consider that Sraffa's use of Saint-Simonianism, despite its significance, does not express an enduring interest. The presentation of the second moment, despite its uncertainties, nevertheless suggests that this is not the case.

\section{The second moment (1959?-1967): a project to publish Saint-Simon's works? (manuscripts $\mathrm{H3} / 24$ and $\mathrm{H3} / 25$ )}

The second moment, although based specific sources, is of a much more uncertain nature and the Sraffian project more enigmatic, relative to the state of our current knowledge. This time it concerns only Saint-Simon, the master, excluding the members of his School. In presenting it, we follow the same approach as in Part I.

In terms of form, the relevant manuscripts are contained primarily in the two boxes of the Unpublished Papers on Saint-Simon, essentially H3/24 with 16 sheets (in particular the folder "Saint-Simon index" and "Notes and quotations on Saint-Simonianism") and H3/25 ("Notes on Saint-Simon manuscripts") with 148 sheets; but other elements can be added (also H1/16 Photocopy of printed correspondence between Saint-Simon and Redern; H1/17 Photocopies of articles from La Nef and Zeitschrift für Schweizerische Geschichte on Saint-Simon's Project d'Encyclopedie and copies of manuscript and printed copies of Saint-Simon's letters to Redern); ${ }^{46} \mathrm{H} 1 / 18$ (Photocopy of a political work by [Saint-Simon]) and H1/19 (Microfilm of Saint-Simon's manuscripts in the National Library). ${ }^{47}$ The set of documents is sizeable, but contains absolutely nothing that could be thought relevant to the first moment. Indeed, it is composed of partial sources, which appear disparate at first, on various media (agendas,

\footnotetext{
${ }^{46}$ The NEF (Nouvelle Equipe Française, a monthly journal published from 1944 to 1951, 1st series) with an article and a presentation by H. Gouhier ("Deux théoriciens de la paix. Henri de Saint-Simon et l'alliance francoanglaise," and "Henri de Saint-Simon. Projet d'Encyclopédie ") of July 1946. The article in the Zeitschrift für Schweizerishce Geschichte dates from 1925 and concerns the Lettre aux habitants de Genève, de Saint-Simon, by Paul E. Martin (477-97).

${ }^{47}$ There are also elements scattered in H3/48.4, 48.5, 48.9, and a reference to the Cuvres de St Simon et Enfantin in ed. Dentu (for examination of the Works of St Simon only) in H3/54.
} 
tickets, etc.), with writing in English, French, Italian. There is a mass of references from copied sources, but also quotations, summaries, sometimes reflections, ${ }^{48}$ and even proposals for modifications or reformulations of Saint-Simon's text to make it more accurate, ${ }^{49}$ as well as a search for original manuscripts (see the continuous "Mss St-Simon" notebook on Notebook Century, with 11 pages of notes on microfilmed manuscripts from NL H3/25). The sources searched and used by Sraffa on Saint-Simon are also diverse, but systematic:

- Partial publications of Saint-Simon's works already existing (Euvres choisies de Saint-Simon et d'Enfantin de 1859 sous la direction de B. P. Enfantin et du conseil institué par P. Enfantin, Euvres de Saint-Simon et d'Enfantin of 1859 under the direction of Charles Lemonnier (Brussels), selected texts of L'euvre de Saint-Simon by Bouglé and the bibliographic record of A. Pereire, of 1925).

- Resources related to collections and libraries: Fonds Léon de la Sicotière, with the November 1959 deeds of sale of this very famous collection, Fonds Enfantin, Fonds Pereire, Biblioteca-Instituto Feltrinelli from Milan, Bibliothèque Mazarine, Bibliothèque Nationale, requests to the National Archives on Rigomar Bazin (a close friend of Saint-Simon). Notes and references on documents, manuscripts, prints, microfilms, sometimes very precise (e.g. Sraffa notes manuscript confusion, duplicate versions, etc.).

- Potential resources related to private booksellers specializing in Saint-Simon.

- The essential French and international works on Saint-Simonianism (by F. Muckle, H. Gouhier, M. Leroy, C. Bouglé, G. Weill, H. D’Allemagne, and F.E. Manuel).

Nevertheless, Saint-Simon remains at the core of this accumulation of documents. Thus DSS, written by the disciples after the death of the master, is mentioned only once. When there is a reference to Le Producteur (only the $3^{\text {rd }}$ volume of 1826), it concerns, as we have been able to verify, Rodrigues's series of four articles on Saint-Simon, and, in particular, the only article that refers to the Projet d'Encyclopédie and the definition Saint-Simon gives it, which is, as

\footnotetext{
${ }^{48}$ For example, Sraffa's remarks in H3/25.12 on perfectibility: "This idea is, no doubt, Perfectibility"; or almost all of p. 17 where we find other Sraffa's references in French: "Vulgarisateur, avocat de la Science"), or even p. 23. ("L'auteur injurie trop D'Alembert qui vient de dire une chose juste"). We keep French langage here.

${ }^{49}$ For example, pages 19, 20 and 21 in H3/25 on Saint-Simon's Projet d'Encyclopédie (1810) refer to SaintSimon's text which states, "il est impossible de faire de la bonne philosophie sans avoir étudié la physiologie." Sraffa then states in French (p. 19): “je crois cela faux, car si l'on excepte Bonnet et Cabanis, il n'y a jamais eu de philosophie qui sut la physiologie: mais enfin c'est une opinion très libre; je préfèrerais pourtant que l'auteur dit qu'il est impossible de savoir tout ce qui appartient à la philosophie sans avoir étudié la physiologie." We keep French langage here.
} 
we will see below, probably not insignificant. Having undertaken a precise reading of this set, it appears to us that Sraffa brings together in an ordered, detailed, and systematic way the components of Saint-Simon's texts.

To estimate the period over which Sraffa collected this mass of references and sometimes assessments, we only have the date attached to the two main boxes of documents (that of 1960), certain documents from boxes H3/24 and 25 which clearly show that this work was in progress in 1959 (notes on the agenda of late December 1959-23 January 1960 in H3/24, request to consult books at the Feltrinelli library in March 1960 (H23/25.54), official response of the National Archives to a request of September 1960, in H3/25) and finally oral testimonies regarding Sraffa's intentions (below). ${ }^{50}$ Thus, this collection seems to have stopped in the spring of 1967. The probable period of this intense and systematic work of collection and reading would therefore cover the period from late 1959 to early 1967 . At the beginning of the period, Sraffa was therefore still in the process of editing The Works and Correspondence of David Ricardo, but had deposited the manuscript of what would become his only book Production of Commodity by Means of Commodities (1960) and had adjusted its publication characteristics in line with the publishers' wishes (Einaudi and Cambridge University Press). At the end of the period (1967), Sraffa was still working on the general Index of the Works of Ricardo (which would constitute vol. XI). ${ }^{51}$

Concerning the relationship between these documents and Sraffa's intention, there are currently only two indirect references to what appears to be a project to publish SaintSimon's works. First, that of economist Meldolesi in June 1981 (published in 1982) about a discussion with Sraffa in spring $1967:^{52}$

Il suo punto di partenza è una conversazione avuta con Piero Sraffa nella primavera 1967. Egli mi disse che, a suo guidizio, l'analisi politica di Marx era stata in larga misura anticipata da Saint-Simon; che aveva già raccolto gli

\footnotetext{
${ }^{50}$ This concerns the person and work of Jacques Rigomar Bazin. Sraffa undertook research on this author, a friend of Saint-Simon, because there was sometimes doubt about his writings: his Epître aux dames was sometimes attributed to Saint-Simon (H3/25: 23 to 25).

${ }^{51}$ The complete edition of the Works and Correspondence by Cambridge University Press would run from 1951 to 1973 .

${ }^{52}$ In Sraffa's diary we find a handwritten mention of a meeting with Meldolesi on 22 May 1967 (UP, E39). We keep the Italian language here.
} 
scritti sparsi di questo aurore, ma che, probabilmente, qualcun altro avrebbe dovuto compiere il lavoro: Sraffa si sentiva ormai troppo vecchio per condurlo a termine. («Parlo di Saint-Simon, non di Sismondi » aveva esclamato, quasi infastidito dal moi sgardo incredulo - come dire: lo so, su questo argomento i miei interlocutori prendono fischi per fiaschi - . «I suoi seguaci - prosegui Sraffa- indossavano un abito allaciato sul dietro, in modo che ciascuno dovesse aiutare l'altro ad indossarlo, come simbolo di fratellanza.

Sraffa aveva pensato di ricostruire appunto questa « grandiosa concezione generale », seguendo lo stesso metodo usato per la nota edizione delle opere di Ricardo. (Meldolesi Luca, 1982, L'utopia realmente essistente. Marx e SaintSimon, Bari, Laterza, Prefazione :VIII, then chap. I: 3)

Second, that of the economist Sergio Serve, made in February 2003, during the Convegno internazionale on Piero Sraffa in Rome:

Ed è daverro difficile capire come Sraffa potuto compiere tutto quel lavoro se si tiene conto che oltre all'edizione di Ricardo ci fu non solo il suo lavoro teorico, ma altri interessi di studio, come le ricerche su Saint-Simon e i sainsimoniani, condotte negli achivi et nelle biblioteche francesi, e poi abandonate perché decise che quegli autori erano noiosi. (Steve Sergio, Testimonianza di un amico, in 2004: 14). ${ }^{53}$

In view of these elements, and the absence of any known written documents by Sraffa concerning this (grandiose) project on Saint-Simon, we can only put forward some conjectures seeking to shed light on the potential significance of this second moment in his relationship to Saint-Simonianism.

First conjecture: it represents simply an interest of a bibliophile buyer and collector, which obviously Sraffa also was. This seems plausible for some of the references (e.g. in H3.10 and

\footnotetext{
${ }^{53}$ The 2001 English version ("A Memoir”) is not totally identical: "The work on Ricardo is in itself sufficient to disprove the common assumption that Sraffa was a lazy and inconclusive man. And at the same time there exist many more, little-known examples of his work: on the witches' trials, on the curate Meslier's testament, and above all on Saint-Simon and the Saint-Simonians - research conducted in the French archives for years before being abandoned because the authors were considered too tedious."
} 
H3.43 concerning the first year of the Doctrine, where buyer concerns seem to be the motivation). But this conjecture is not very defensible given the enormous significance of the research and grouping work undertaken by Sraffa, his insistence on collecting sources, and finally the oral testimonies of Steve and Meldolesi. In our opinion, when we carefully read the two main sets of documents compiled by Sraffa on Saint-Simon (H3-24 and H3-25), there is no doubt that he was willing to undertake editorial work, perhaps as meticulous as that undertaken concerning Ricardo. In the Sraffa library (Catalogue, 2014), there are 18 publications (purchased in 1st ed.) of different works by St-Simon, to which must be added a reedition of the first text of St-Simon (Lettre d'un habitant de Genève à ses contemporains, 1802), largely annotated by Sraffa himself, an edition of the selected texts of St-Simon by Bouglé (1925), the text of Augustin Thierry, then secretary of St-Simon (Politique, 1817), the collective work of St-Simon and the first circle of disciples, Opinions littéraires, philosophiques et industrielles (1825) and the edition of the Doctrine de St-Simon. Exposition by the St-Simonian disciples (1830), in the reference edition of Halévy-Bouglé (1924). To this must be added the Saint-Simonian newspapers Le Producteur (1825-1826) and L'Organisateur (1829-1831), and 15 acquisitions of French, American and Italian specialized works on Saint-Simonism (from 1831 to 1963). ${ }^{54}$ De Vivo himself, during his work to develop the catalogue of this library in Sraffa (2014), does not seem to doubt the reality of this project:

"There is a remarkable collection of the works of Henri de St. Simon, from whom Sraffa had a great interest, testified to also by the amount of his manuscripts which he put together - indeed he had planned to edit theses manuscripts for publication, doing for St Simon something similar to what he had done for Ricardo (this project came to nought...”(Catalogue, 2015: XLIV).

However, even if we reject conjecture 1, this does not shed any light on the justification for this project.

Second conjecture: it represents a project within the history of thought to publish Saint-

\footnotetext{
${ }^{54}$ The only missing item in this collection is the edition of the Euvres de Saint-Simon \& d'Enfantin (published by the members of the Council instituted by Enfantin for the execution of his last wishes, edited by E. Dentu from 1865 to 1876 , then by E. Leroux, 1877-1878, 47 volumes). This exception may be explained by the fact that this edition is more oriented towards the work of the disciple than that of the master, which is scattered in 11 different volumes). However, Sraffa, in his Papers, sometimes uses this edition, and has therefore consulted it, as mentioned above
} 
Simon's entire works. Sraffa's scholarship in the history of economic thought is well known. While he continued his long effort to publish Ricardo's works, Sraffa was also a consultant on publishing economist authors. In 1933, Giulio Einaudi, the son of the Professor Director of Sraffa's thesis, founded the Einaudi publishing house. In 1948 G. Einaudi wanted to launch a collection of "classical economists" (Collana dei "Classici dell'economia") and asked Sraffa for his opinion on a list of authors to publish, according to the publisher: Petty, Quesnay, Smith, Ricardo and Marx's Capital. Sraffa said he wanted to include Marx's History of Economic Theories as a priority, followed by Petty, Smith, Quesnay, Ricardo, and Cantillon. The collection (BCE) was created in 1954, with Sraffa as advisor. A first volume dedicated to the Marx's History of economic theories was planned (with introduction by Maurice Dobb, translated by Elio Conti), the two other volumes were planned for 1955 and 1958 (and also Cantillon in 1955 and Luxembourg in 1960). Finally contact was made with specialists in the history of economic thought (Jaffé on Walras, for instance). However we find no reference to Saint-Simon within the context of this project, which is not all that surprising, because it is undoubtedly difficult to classify Saint-Simon among the so-called classical economists, and thus for example to risk presenting Saint-Simon as the point of passage between Ricardo and Marx on the field of economic surplus analysis. In Sraffa's recommendations for a collection such as "Biblioteca dell'Economista" or "Biblioteca di cultura economica," the volumes considered in 1952 concern Hicks (with strong reservations), Hilferding, Ricardo, Malthus, Verri, Böhm-Bawerk, and Sismondi. Sraffa proposed to include Hobson (Imperialism), strongly recommended Sismondi, and is reluctant to publish his Ricardo volumes separately (Sraffa 2017). ${ }^{55}$ But Saint-Simon is not reported here either. Clearly, as it stands, there is no written record of the Sraffian project to publish Saint-Simon's works in the history of economic thought. The only indirect reference is a response from Sraffa to G. Einaudi in March 1949 concerning a project by the economist R. Banfi (a collection of political economy in eleven volumes, the fifth of which would concern "utopians"). However Sraffa's overall opinion on this project is caustic and negative, in particular challenging the sociological point of entry envisaged by this project, whereas in his view it should be "Marxist." ${ }^{, 56}$ Nevertheless, a complete examination of the letters still needs to be carried out, at least over the period involved (1959-1967), to be certain of this absence of trace.

\footnotetext{
${ }^{55}$ Within the selection made by T. Munari, see letter to G. Einaudi of 23 October 1947; letter to G. Inaudi of 21 October 1948; letter to G. Audi of 30 October 1948; Appendix 1 and Appendix 2 of January 1952 on the collection "Biblioteca di cultura economica" and on the collection "Classici dell'economia" (Sraffa 2017, respectively: $12-14,38-39,44-47,169-178)$.

${ }^{56}$ Letter to G. Einaudi, 6 March 1949 (Sraffa 2017: 57-58).
} 
Third conjecture: is it then a project related to Marx (cf. Meldolesi 1983), which would be less economic than political, concerning Saint-Simon as an inspiration for Marx ${ }^{57}$ It is difficult to make a decision here, and it would then be necessary to return to the question of the links between Sraffa and Marx, which are still full of debates (see the partial synthesis of Bellofiore 2010, and recently De Vivo 2017, ${ }^{58}$ and the differences of interpretation with Naldi on this point). Sraffa's knowledge of the various strands of socialist and Marxist interpretation (Grazadei and the so-called revisionist quarrel, Gramsci, Rosselli, Gobetti, Turati, etc.), his relations with a more traditional Marxism (Dobb and Meek), and his possible willingness to reinterpret Marx's political project based on his borrowings from Saint-Simon, beyond the simple categorizations in terms of "utopian socialism" project.

Fourth conjecture: Sraffa, adopting a highly "scientific" and "objectivist" approach, was undertaking a methodological and philosophical project concerning knowledge in the mathematical and physical sciences. This conjecture might have some plausibility insofar as Sraffa, in the Unpublished Papers related to Saint-Simon, shows a strong insistence on the socalled scientific part of Saint-Simon's work - that part devoted to science, encyclopedia, relations with Bichat, Cabanis, Cuvier, Carnot, Condorcet, Lamarck, Gall, etc., scientists that Saint-Simon sometimes met to train himself. What seems to interest Sraffa in Saint-Simon is thus the Introduction aux travaux scientifiques du XIXème siècle of 1807-1808 (with the encyclopedic tree), the Projet d'Encyclopédie (1810), and the Plan d'une nouvelle Encyclopédie up until the Travail sur la gravitation universelle et au Mémoire sur la science de l'homme (1813), in short what are called the texts on sciences ${ }^{60}$ (Cf. p. 89-90 including many other references in the Unpublished Papers). It would then be necessary to engage in the debate comparing the reading of Kurz and Salvadori $(2004,2008)$ and Porta (2013), Davis (2012) or Ginzburg (2015) and Arena (2015) and to see to what extent it is possible to place

\footnotetext{
${ }^{57}$ Let us recall that Meldolesi regards the thought of Marx and Marxism (or at least a side of Marx and a part of Marxism) as "a left-wing Saint-Simonianism." He then proposed to develop the strictly Saint-Simonian dimension of a modern socialism by combining the power of managers and that of scientists.

${ }^{58}$ Appendix to Chapter II.

${ }^{59}$ Engels's book on Dühring was published in Italian (Il socialismo scientifico contro Eugenio Dühring) in 1911 (Milano-Palermo, Remo Sandron, trad. Sofia Puritz with an introduction by Bernstein). Gobetti and Rosselli exclude the Saint-Simonian "utopia" from playing any role, even a purely inspirational one, in defining modern socialism, especially in Italy. However, there is a tradition of studying the relationship between Marx and SaintSimon (notably Andler, Gurvitch, Perroux, Prochasson, and of course Meldolesi).

${ }^{60}$ This covers almost all of volume 1 of the Complete Works, in the recent French scientific edition (2012).
} 
Sraffa's Saint-Simonian project in this perspective. On this conjecture, it would have been a profound philosophical theme of Saint-Simonianism, namely his physiology of organization ${ }^{61}$ resulting from a reinterpretation of the scientific work of his day, that could have interested Sraffa. The concept of the organic society, for example, according to Gramsci, is linked to Saint-Simon and Comte. ${ }^{62}$ It may also be noted that if, in Italy, the influence of SaintSimonianism was channelled by an interpretation of its project as a humanitarian religious socialist project, it was also subject to another reading: that of a positivism applying rigorous methods to history and society as a whole (Saint-Simon, Bazard and Comte are then privileged).

Fifth conjecture: this is a simpler hypothesis, based on Sraffa's personal curiosity, which was tireless, but also hesitant at a time when he was about to complete the publication of Ricardo's works. Sraffa had embarked on other similar projects (albeit less systematically) and then abandoned them. For example, there is a partial collection in the Unpublished Papers concerning other authors associated with "utopian socialism" such as Owen, and a collection concerning the priest Jean Meslier (I.10, I.11, I.12, during the 1950s and 1960s, with a final incursion in 1973). Moreover, an significant, although incomplete, Italian edition of Saint-Simon's Euvres appeared in 1975 (Saint-Simon Opere, a cura di M. T. Bovetti Pichetto, Torino, UTET, ed. Classici della Politica - collezione diretta da Luigi Firpo, 1162 p.), as if to close the book upon Sraffa's project at Cambridge ${ }^{63}$. However, this conjecture runs up against the sheer size of the work undertaken by Sraffa, which remains unique compared to the various other authors which caught his interest (except Ricardo).

Given our existing knowledge, Conjecture Four seems an important line of future exploration, provided that its content is clearly defined in relation to what is usually discussed under the terms the "objectivist Sraffa" (Kurz, Salvadori 2004, 2008) or the "physicalist Sraffa" (Davis 2012). Indeed, these adjectives have been used primarily in relation to the Sraffian conception

\footnotetext{
${ }^{61}$ The basis of Saint-Simon's work, including its understanding of the social world and the "march of the human spirit" in conformity with the "march of things," is the distinction between corps bruts and corps organisés (raw/organized bodies) on the one hand, and the distinction between solids and fluids on the other. The role of the physician and medical science were seen as central to this construction. Physiology is then defined as the science of the functioning of organized beings, as well as of society as an organized totality

${ }^{62}$ "Le "proposizioni” economico-sociali di Eugenio Sue sono legate a certe tendenze del Saint-Simonismo, cui si collegano anche le teorie sullo Stato organico e il positivismo filosofico" (Quaderno 3, 53: 334).

${ }^{63}$ Sraffa may also have been sensitive to the French edition of the CEuvres complètes de Saint-Simon, in 6 volumes, by the publisher Anthropos, in 1966, completing the old incomplete edition of Dentu. However, this new edition was still incomplete.
} 
of surplus and the questions raised by Marx's theory of labour value. Still based on a reading of the Unpublished Papers (1931, D3/12/7 "Surplus Product", then post 1931), these commentators underline Sraffa's desire to base a theory of surplus and distribution on the nature of material things: that of production costs as real physical costs, in opposition to the subjective (marginalist) view in economics. To Sraffa, these physical costs must also be measurable. This desire for value theory is itself explicitly linked to an "objective point of view" and a "natural science point of view": it would therefore engage a broader philosophical and methodological conception of Sraffa's views concerning science (objectivism, or physicalism to the extent that the language of the physical sciences appears necessary to any scientific perspective). What then might be the relation between this conception and Saint-Simonianism? On this question we must be clear: in our opinion, there is no concept of surplus in Saint-Simon and his disciples, and no clear notion of reproduction. In this respect, the Saint-Simonian approach falls below that of Quesnay, Ricardo and Marx. There is therefore no justification for adopting this perspective. On the other hand, if we are to try to grasp Sraffa's link with Saint-Simon (and Marx), the common "objectivist" basis that might have interested Sraffa more than a century later could have three dimensions. Let's present them very briefly here:

First, the general relationship which Saint-Simon had with the science of his time. SaintSimon tried to base his philosophy on foundations related to the "positive" sciences (i.e. based on observation), which he opposed to "conjectural" sciences. These foundations are physical and physiological in nature: solids/fluids and corps bruts/organisés, as indicated above; physiology is though to be the physics of organized bodies. To this end, Saint-Simon spent a large part of his training integrating the scientific knowledge of his time and drawing a general vision out from it. Saint-Simon's obsessive concern for encyclopedias and the desire to propose a new one testifies to this. "Great Cuvier, scientist Duméril, learned Lamarck, good Geoffroy, ardent Blainville, ingenious Gall, why didn't those who will look at these lines take your lessons?"(Redern 1811-12 in O.C. 2012, T1: 815. We translate). ${ }^{64}$ As noted above, for Saint-Simon, "it is impossible to do good philosophy without studying physiology" (1810[2012] Draft Encyclopedia, second edition: 668. We translate): in his rare remarks

\footnotetext{
${ }^{64}$ Sraffa's following remark on the importance of the world of science can perhaps be compared to the St. Simonian conception: "È un fatto curioso che nella cultura di tutti gli italiani che hanno una cultura vi sia un gran buco: l'ignoranza delle scienze naturali. Croce è un caso estremo, ma tipico. I filosofi credono che, quando han provato che gli scienziati sarebbero degni di essere vergognosamente bocciati in filosofia, il loro compito sia finito" (Lettre à Tania, 23 August 1931: 96. We keep Italian language here).
} 
(H3/25), Sraffa notes and comments on this "objectivist" and unifying point of view, which is at the heart of the Saint-Simonian project. ${ }^{65}$

Second, the global scope of this objectivism in Saint-Simon: for him, "objectivism" is fundamental to the sciences of man and society-whether psychology, history, politics, or political and moral economy, these are not sciences without such a foundation. In his first book, Saint-Simon wrote: "My friends, we are organized beings, it is by considering as physiological phenomena the social relations that I have conceived the project that I present to you " (Lettres d'un habitant de Genève à l'humanité / à ses contemporains, 1802/1803, in 2012, vol. I, 1st letter: 118. We translate ${ }^{66}$ ). Saint-Simon substitutes the Condillac's physiology of the sensation for a physiology of the organisation (in the sense of a physiology of organized bodies). All human activity, individual and social, must be thought within the framework of the development of this organization; consciousness and intelligence are necessarily collective before being individual, because they depend on an organic unity of the species, and are only an outgrowth of this dynamic of physiological organization which gradually becomes more complex. The history of life and society is simply the deployment of this dynamic over time and of perfectibility (Condorcet's "marche de l'esprit humain"); there is nothing more than the translation of the latter. According to Saint-Simon, Condorcet's definition of this "marche" is insufficiently based on physiology. Human history is, in this sense, integrated into the development process of material reality. The "nature of things" (a recurring expression in Saint-Simon's work) concerns both the laws of physics and the laws of the social and moral world. The creation of wealth (and therefore political economy) by the triad of human activities science-industry-art, itself based on three dimensions (idea-actionimagination), is part of this global process. Thus, after the period of Saint-Simonian scientific work aimed at establishing a philosophy of science, the so-called "industrialist" period (an industry deeply linked to its material foundations, of course), and even the so-called religious period (a terrestrial religion, of course), are incomprehensible absent the physiological reference point. This founding relationship to science induces a philosophical unity and a unity of method. Sraffa notes in his quotations from Saint-Simon's writings on moral sciences: "au lieu de 'telle est en effet la base des sciences morales', on pourrait mettre: que

\footnotetext{
${ }^{65}$ On the emphasis on physics and physiology in Saint-Simon's approach, the best work remains Frick 1984.

${ }^{66}$ See also: «The purpose of my work is to perfect political science. It seemed right to me to base this science on observations and therefore to elevate it to the level of positive science. I have undertaken, in a word, to create physico-political science..." (Eléments préparatoires du Projet d'Encyclopédie, manuscrit, about 1808, in $O C$ 2012, vol. 1: 441. We translate).
} 
les sciences morales doivent être traitées comme les sciences physiques, parce qu'il n'y a pas deux bonnes méthodes pour l'esprit humain"; and also "au lieu de "elles [sciences] ne seraient plus qu'une branche', mettre: elles seraient pour ainsi dire une... etc..." (H3/25.20. We keep the French language).

However, Saint-Simon cannot be accused of a return to reductionist and mechanistic materialism. Indeed, even if the mental dimensions are based on physical states (brain and nervous system in particular, taking into account the work of the time such as that of Gall and others ${ }^{67}$ ), human processes have a specific character, and reflect in a particular way the real physiological processes. ${ }^{68}$ The organization of societies is not a simple transposition of physiological organization and Saint-Simonianism is not an organicism. Similarly, SaintSimon, opposed to a mechanistic interpretation, contests any interpretation in terms of the "corps bruts" of physics and mere causality, which misses the emergence of a complex reality. According to him, social reality is indeed a hierarchical and dynamic organization (an organized body), but the organizational process involves interactions, network effects, and a causality that is not unique: for example, there is no indefinite perfectibility as in Condorcet, because there may be the acquisition of new faculties, and at the same time a decline in others previously acquired. Similarly, the historical phases are not mechanically linked and do not have the same status: we find at Saint-Simon a early first formulation of the "critical" phases and "organic" phases, which Saint-Simon's disciples will codify more strictly. It is not possible to say whether this dimension was perceived and commented upon by Sraffa, since it is in Saint-Simon's historical, industrial, and moral works that it appears most clearly, and Sraffa stopped his work before clearly addressing this field. However, the proposals to correct Saint-Simon's formulations are in line with a non-reductionist and non-mechanical approach. We can see for example the brief notations on causality and exclusive cause (H3/25.20). Sraffa read the essential text entitled "Social Physiology" and the two issues of the "Thesis on Human Science". He also read Enrico Vidal's very solid book (1959) on political science at

\footnotetext{
${ }^{67}$ Symbolically, and in passing, let us note that Gall was called to the bedside of Saint-Simon in May 1825 and autopsied his skull.

68 "At Saint-Simon, we find the breadth of view of a genius to whom we owe most of the ideas of future socialism, which is not strictly economic " (Engels 1892; this sentence is not found in the book on Dühring, nor in the first text of 1880 and has been added in the English edition of 1892). At Saint-Simon hismself (Le politique (1819-20): in O.C. 2012, t. III: 2007-2008): « As for us, we believe that politics must be a sister of astronomy, chemistry and physiology, and that it must not be directly generated by any of them. In a word, it seems to us that the series of historical facts that record the progress of civilization is just as good and as solid a basis for political science as the series of observations on the progress that the stars have followed to found the science that aims to calculate the progress that they will follow. » (We translate).
} 
Saint-Simon, which he had acquired (see Catalogue, 2014).

On this triple characteristic, Saint-Simon is unique, and goes well beyond the organicist metaphors common as regards the social body (for instance, from François Quesnay to JeanBaptiste Say). We can venture to argue that Sraffa may have been attracted by the thoughts of an author who was so concerned about the sciences of his time, and whose positivism pointed him towards the physical sciences but not to mechanistic materialism-and who perhaps reminded him of Marx's relationship to Darwin. We also see by this that Conjecture Four is not necessarily in contradiction with Conjecture Three.

However, we can object to Conjecture Four that Sraffa may have engaged in his work of collecting and classifying (and sometimes making remarks on) Saint-Simon's complete works in the chronological order of the author's own works, and that beyond a certain date he could not continue. This would thus cover the work of Saint-Simon from 1802 (Lettres aux habitants de Genève) to 1816-1817 (L'industrie) and would in fact focus only on the socalled scientific part of the works. An interpretation bias would therefore be created simply because of the interruption of Sraffa's work around 1967. However, one can only be struck by the notations and personal additions of wording made by Sraffa on the Saint-Simonian texts, of which some examples have been given here, and we can believe that Sraffa perceived the unity of analysis of the Saint-Simonian work based on his philosophy of science.

\section{Conclusion}

Sraffa's work does indeed provide us with an example of the ongoing relevance of Saint-Simonianism in economics, in this case from the nineteenth century to the twentieth century. This topicality, albeit obviously based on a re-reading, is expressed in its first moment (1929-1930) in the analysis of the changes in the capitalism of the inter-war period (banking and financial system, rationalization, concentration, active role of monetary policies), in the same way that we find it in Mason on certain sometimes related themes, and in the same years. ${ }^{69}$ In the projects and achievements of the nineteenth century, Sraffa has undoubtedly found a point of support for his work that is not limited to the most famous references to practical Saint-Simonianism (banking, railways, etc.), nor to a thesis on

\footnotetext{
${ }^{69}$ See Frobert (2018), "Back to the future: Edward Mason, reader of the Saint-Simonians."
} 
investment banking that is in fact quite trivial. This reading feeds into a new interpretative perspective on the integration of banking into a global banking system, on the specificity and relativity of various banking systems, and above all on the importance of institutions in embodying financial innovation, stabilizing it, and the possibility of its temporal (here from the 1860 s to the end of the 19th century and the beginning of the 20th century) and spatial (here from France to Germany) transposition. It has also been an attempt to show that Sraffa did not propose an updating of the interpretation of Saint-Simonianism in the simple terms of an anticipation of the future (the Saint-Simonian industrial bank anticipating universal banking), but tried, through the case of the Crédit Mobilier, to set out the institutional conditions that made the past present. The Saint-Simonian references which structure the lessons contained in his course Continental Banking certainly suggest we should explore the role of institutions and conventions in Sraffa's economic analysis, as well as its position in relation to history. But Sraffa's use of Saint-Simonianism also sheds light on the interpretation that can be made of this intellectual movement. On the banking issue, it makes it possible to avoid reducing it to a somewhat crazy experience of the Pereire's linked to a "utopian" plan. It also invites us to explore the place of Saint-Simonianism in Italian culture in the 1920s and 1930s, particularly in Turin. We were thus able to glimpse the intertwined connections and works (articles in the Riforma Sociale, Mosca's role, Treves' thesis, etc.) which could have influenced Sraffa, albeit without yet being able to systematically survey this potential ground.

The second moment of revision remains more open on the interpretative level. It would give a more global meaning to the use he made of Saint-Simon in 1929 and the 1930s. We have outlined an interpretative conjecture of the Sraffian project that does potentially make sense, and that can posit a link between Saint-Simon and Marx on a basis that would not be specifically economic, but would more broadly concern the philosophy of science and the philosophy of history. This field, it should be noted, is very similar to Hayek's three articles (1941, then 1952) which also afforded Saint-Simon the status of "accoucheur d'idées," but in a very different methodological sense: indeed, Hayek rejects Saint-Simon's "scientism" and "objectivism," i.e. his tendency to imitate the natural sciences in the social sciences (with references to texts on science and physiology very similar to those adduced by Sraffa). This conjecture then seems less surprising and Staffa's interest in Saint-Simon's scientific perspective less isolated than one might have thought. But this conjecture remains fragile. In any case, Sraffa's work is an additional and often still underestimated testament to the modern 
reactivation of Saint-Simonianism.

\section{Bibliography}

\section{Moment 1:}

Autin, Jean. 1984. Les frères Pereire. Paris, Perrin.

Aycard, Maurice. 1867. Histoire du Crédit mobilier 1852-1867. Librairie internationale, Bruxelles, Leipzig, Livourne.

Baldy, Edmond. 1922. Les banques d'affaires en France depuis 1900, thèse pour le doctorat, Faculté de droit de l'Université de Paris, Paris, Librairie générale de droit \& de jurisprudence.

Barbaroux, Nicolas and Lutz, Adrien. 2018, "A theoretical and practical analysis on SaintSimonian in money and banking in 19th century," Paper presented to ESHET 22e Conference, Madrid, June 5-8.

Barrett Whale, Philip. 1930. Joint Stock Banking in Germany: A Study of the German Creditbanks before and after the War, London, Frank Cass.

Blankenburg, Stéphanie, Arena, Richard and Wilkinson, Frank 2012. «Piero Sraffa and 'the true object of economics': the role of the unpublished manuscripts ", Special Issues: New perspectives on the works of Piero Sraffa, Cambridge Journal of Economics, 36, 1267-1290.

Cameron, Rondo E. 1953. "The Credit Mobilier and the Economic Development of Europe", Journal of Political Economy, Vol. 61: 461-488.

Collective author, 1924 [1831], Doctrine de Saint-Simon. Exposition. Première année, 1829, $3^{\text {ème }}$ ed., nouvelle édition publiée avec introduction et notes par C. Bouglé et E. Halévy, Paris, Marcel Rivière. English translation by Iggers Georg G., 1972. The Doctrine of SaintSimon. An Exposition. First year, 1828-1829. New-York, Schocken Books.

Confalioneri, Antonio. 1974, Banca e industria in Italia (1894-1906), vol. I: Le premesse: dall'abolizione del corso formoso alla caduta del Credito mobiliare, Milano, Banca commerciale italiana.

D’Orsi, Angelo. 2000, A child of Cultura Positiva: Turin and the education of Piero Sraffa, in Cozzi T., Marchionatti R. (ed.), Piero Sraffa's Political Economy. A Centenary Estimate, London, Routledge, chap. 1. 
D’Eichthal, Gustave. 1929, Lettres à MM. les députés composant la Commission du Budget sur la permanence du système de crédit public, et sur la nécessité de renoncer à toute espèce de remboursement des créances de l'Etat, Paris, Librairie centrale.

Davies, Helen M. 2015, Emile et Isaac Pereire. Bankers, Socialists and Sephardic Jews in nineteenth-century France, Manchester, Manchester University Press.

De Cecco, Marcello. 1993, Piero Sraffa's Monetary Inflation in Italy during and after the War': an introduction," Cambridge Journal of Economics, vol. 17, No.1: 1-5.

De Cecco, Marcello. 2005, "Sraffa's lectures on Continental banking: A preliminary appraisal" Review of Political Economy, Volume 17, Issue 3, Special Issue: Piero Sraffa 1898-1983, pp. 349-358, reprinted in Kurz, Heinz D., Pasinetti, Luigi and Salvarori, Neri (ed.) 2008, Piero Sraffa: The Man and the Scholar. Exploring the unpublished papers, (ed.), London, Routledge: 187-190.

De Cecco, Marcello. 2013, Sraffa's Lectures on Continental Banking, in Levrero E.S., Palumbo A., Stirati A. (ed.) Sraffa and the Reconstruction of Economic Theory: vol. Three, Sraffa's Legacy: Interpretations and Historical Perspectives, Springer: 174-188

Faucci, Riccardo and Rancan, Antonella. 2009, « Transforming the economy: Saint-Simon and his influence on Mazzini," History of Economic Ideas, Vol. 17 (2): 79-105.

Federici, Luigi. 1922, Saint-Simon, Napoli, Morano (prefazione di G. Mosca).

Gentile, Francesco. 1969, Saint-Simon in Italia, Emozioni e risonanze saint-simoniane nell'Ottocento italiano, Napoli, Morano; $2^{\text {sd }}$ ed. 1971; reprint in French in Perroux, François, Schuhl P.-M. (sd), 1979, Saint-Simonisme et pari pour l'industrie. XIXèmeXXème siècles. III, Economies et sociétés, tome IV, No.10, october: 421-484.

Gentile, Francesco. 1971, Ancore su Saint-Simon in Italia, 3p

Gerschenkron, Alexander. 1962. Economie Backwardness in Historical Perspective. A. Book of Essays, Cambridge, Mass., Harvard University Press.

Guéroult, Adolphe. 1956, Emile Pereire, in Théophraste, Etudes critiques et biographiques, tome III, Paris.

Jacoud, Gilles, 2017. L'analyse du système de Law par les saint-simoniens, in MagnotOgilvy F. (ed.), Gagnons sans savoir comment !: représentations du système de Law du XVIIIe siècle à nos jours, Rennes, Presses Universitaires de Rennes: 289-305.

Jacoud, Gilles (ed), 2010. Political Economy and Industrialism. Banks in Saint-Simonian Economic Thought.1825-1832, London, Routledge.

Lafargue, Paul. 1890. «La propriété - origine et évolution». La Nouvelle Revue, Feb. 1st: 526-547. 
Manganaro Favaretto, Gilda. 2004, Quelques réflexions sur le saint-simonisme en Italie, in Musso P. (sd), L'actualité du saint-simonisme. Colloque de Cerisy, Paris P.U.F.: 197-215.

Marcuzzo, Maria Cristina. 2005, « Piero Sraffa at the University of Cambridge ». European Journal on the History of Economic Thought, Vol. 12, 3: 425-452.

Marguerat, Philippe. 2015, Banques et grande industrie: France, Grande Bretagne, Allemagne, 1880-1930, Mission historique de la Banque de France, Paris, Sciences Po. Les Presses.

Marx, Karl. 1856 et 1857, "The French Credit Mobilier", New-York Daily Tribune, 1856: June 21, 24 and July 11; 1857: May 30, June 1 and Sept. 26.

Marx, Karl. 1894 [2004], Das Kapital. Kritik der politischen Ökonomie, Band III, Redaktionsmanuskript Von Friedrich Engels, MEGA2/15. English version On-Line Version: Marx.org 1996, Marxists.org 1999.

Mosca, Bernardo, 1921, "Il pensiero di Saint-Simon considerate dopo un secolo," La Riforma sociale, Rivista critica di economia e di finanza, Vol. 32: 306-336.

Naldi, Nerio. 2009. Piero Sraffa e gli economisti torinese, in Marchionatti, Roberto (a cura), La scuola dei economisti di Torino. Co-protagonisti e epigoni, Firenze, Olschki.

Panico, Carlo. 1988. "Sraffa on money and banking," Cambridge Journal of Economics, Vol. 12, No.1: 7-28.

Panico, Carlo. 2001. Monetary analysis in Sraffa's writings, in Cozzi, Terenzio and Marchionatti, Roberto, Piero Sraffa's Political Economy: A Centenary Estimate, London \& New York, Routledge, Part. IV chap. 18: 285-310.

Pantaleoni, Maffeo. 1895. « La caduta della Società generale di credito mobiliare italiano », Giornale degli economisti, April: 357-429; May: 517-89; November: 437-503. Later in Id., Scritti varii di economia, serie III, Roma 1910: 323-615, reprint in Ercolani G. (ed.), 1998, with an Introduction by Marconi M., Torino, UTET, Roma, Bancaria ed.

Paulet, Elizabeth. 1999. The role of banks in monitoring firms. The case of Credit Mobilier, London and New-York, Routledge.

Pereire, Isaac. 1831. « Leçons sur l'industrie et les finances: prononcée à la salle de l'Athénée ", Le Globe, journal de la religion saint-simonienne, 31 août, 10 septembre, 16 septembre, 24 septembre, 17 octobre, 2 novembre, 13 novembre, 14 novembre, regroupées en 1832 dans un volume, suivi d'un projet de banque, Paris, Bureau du Globe.

Plenge, Johann. 1903, Gründung und Geschichte des Credit Mobilier. Zwei Kapitel aus Anlagebanken, eine Einleitung in die Theorie des Anlagebankgeschäftes, Laupp, Tübingen. 
Riesser, Jacob. 1905, The German Great Banks and their Concentration, National Monetary Commission, Washington.

Saint-Simon, Henri. 2012, Euvres complètes; introduction, notes et commentaires par Grange Juliette, Musso, Pierre, Régnier, Philippe, and Yonnet, Franck, Paris, P.U.F, 4 volumes.

Signorino, Rodolfo. 2005, "Piero Sraffa's lectures on the advanced theory of value 1928-31 and the rediscovery of the classical approach," Review of Political Economy, 17, No.3: $359-380$.

Trèves, Renato. 1931, La dottrina sansimoniana nel pensiero italiano del Risorgimento. Contributo alla storia della filosofia sociale in Italia nella prima metà del secolo XIX. Torino, Istituto giuridico della R. Università (83p.); $2^{\text {ème }}$ ed. augmentée, 1973, Torino, Giapichelli.

Treves, Renato. 1970, Il sansimonismo in Italia. A proposito di un recente saggio, Firenze, Olschki.

Tooke, Thomas and Newmarch, William. 1857, An History of Prices and of the State of The Circulation from 1792 to 1856, vol. VI (1848-1856), London, Longman, Brown, Green, and Longmans \& Roberts.

Vergeot, Jean-Baptiste Albert. 1918, Le Crédit comme stimulant et régulateur de l'industrie. La conception saint-simonienne, ses réalisations, son application au problème bancaire d'après-guerre, Paris, Jouve.

Weber, Adolf. 1922, Depositenbanken und Spekulationbanken. Ein Vergleich deutschen und englischen Bankwesen, Munich, Leipzig.

Weil, Georges. 1894, "Le origini della dottrina di Saint-Simon," La Reforma sociale, rassegna di scienze sociali e politiche, Vol. 1: 427-434.

Yonnet, Franck, 2004, « Claude-Henri de Saint-Simon, l'industrialisme et les banquiers », Cahiers d'économie politique, 46: 147-174.

\section{Moment 2:}

Arena, Richard. 2015, “Order, process and morphology: Sraffa and Wittgenstein," Cambridge Journal of Economics, 59: 1087-1108.

Bellofiore, Riccardo. 2010, "Sraffa and Marx: a reopening of the debate" Dipartimento di Scienze Economiche 'Hyman P. Minsky’ Università di Bergamo. 
Davis, John B. 2012, " The change in Sraffa's philosophical thinking », Cambridge Journal of Economics, 36: 1341-1356.

De Vivo, Giancarlo. 2017, Nelle bufera del Novecento. Antonio Gramsci e Piero Sraffa tra lotta politica e teoria critica, Roma, Caltelvecchi.

De Vivo, Giancarlo. 2014, Catalogue of the Library of Piero Sraffa, Fondazione Luigi Einaudi - Fondazione Raffaele Mattioli, Torino-Milano.

Engels, Friedrich. 1892 [1911]. Il socialismo scientifico contro Eugenio Dühring. Transl. by Puritz, Sifia with an introduction by Bernstein, Edouard, Milano-Palermo, Remo Sandron.

Frick, Jean-Paul. 1984. Le concept d'organisation chez Saint-Simon, Thèse de philosophie, Université de Nancy, reprod. Université de Lille 3.

Gramsci, Antonio. 1929-1933, R. Michels 'Les partis politiques et la contrainte sociale', Quaderni del carcere, Quaderno 2, XXIV, §75 [sur chef charismatique, et rôle des passions, dernière phrase supposée de Saint-Simon]

Gramsci, Antonio. 1930-1932, Owen, Saint-Simon e la scuola infantile di Ferrante Aporti; Sansimonismo, Massoneria, Rotary Club, in Quaderni del carcere, Quaderno 5, IX, §3 e $\S 4$.

Ginzburg, Andrea, 2015, « Two Translators: Gramsci and Sraffa,” Contributions to Political Economy, 34: 31-76.

Hayek Von, Friedrich August. 1941, « The Counter-Revolution of Science » part I, II and III, Economica, February 1941, 8 (29), 9-33; May 1941, 8 (39): 119-150; August 1941, 8 (31): 281-320. Reprinted in 1952, The Counter-Revolution of Science: Studies on the Abuse of Reason, Glencoe, Illinois, The Free Press.

Kurz, Heinz D. 2012, "Don't treat too ill my Piero! Interpreting Sraffa's papers," Cambridge Journal of Economics, 36(6): 1535-1569.

Kurz, Heinz D. and Salvadori, Neri. 2004, "Man from the moon: on Sraffa's objectivism," Economies et Sociétés, Vol. 35: 1545-1557.

Kurz, Heinz D. and Salvadori, Neri. 2008, Representing the production and circulation of commodities: on Sraffa's objectivism, in Kurz, Heinz D., Pasinetti, Luigi and Salvadori, Neri (eds), Piero Sraffa: The Man and the Scholar, London, Routledge.

Meldolesi, Luca. 1982. L'utopia realmente esistente. Marx e Saint-Simon, Laterza, 1982 (avec l'Appendice: Piero Sraffa e il marxismo).

Meldolesi, Luca., 1980. «Piero Sraffa, il percorso di un' analisi e di una cultura e vicenda morale e mentale di un comunista degli anni '20, da Marx a Ricardo (e St Simon)', Il Manifesto, Roma, 6 Giugno, p. 3. 
Naldi, Nerio. 2000, «The Friendship between Piero Sraffa and Antonio Gramsci in the Years 1919-1927 », The European Journal of the History of Economic Thought, VII(1): 79-114.

Porta, Pier-Luigi. 2013, "What remains of Sraffa’s economics," WP series n²42, May, Università degli Studi di Milano.

Potier, Jean-Pierre. 1991, Piero Sraffa-Unorthodox Economist (1898-1983), A Biographical Essay, Routledge.

Saint-Simon de, C.-Henri. 1975, Opere, edizione italiana a cura di M.T. Bovetti Pichetto, Torino, UTET (Classici della politica).

Sraffa, Piero. 2017. Lettere editoriali (1947-1975), a cura di T. Munari, Torino, Einaudi.

Steve, Sergio, 2004, Testimonianza di un amico, in Atti dei Convegni Lincei, Convegno Internazionale Piero Sraffa (Roma, 11-12 febbraio 2003), Roma, Accademia Nazionale dei Lincei: 13-21.

\section{Related to Unpublished Papers:}

Bellofiore, Riccardo. 2012, "The 'tiresome objector' and old moor: a reneval of the debate on Marx after Sraffa based after the unpublished material at the Wren Library," Cambridge Economic Journal, 36(6): 1385-1399.

Bellofiore, Riccardo and Carter, Scott, 2018. Symposium New Directions in Sraffa Scholarship, in Fiorito, Luca, Scheall, Scott and Czupryniak, Carlos Eduardo (eds), Research in the History of Economic Thought and Methodology: Including a Symposium on New Directions in Sraffa Scholarship, Bingley, Emeral Publishing.

De Vivo, Giancarlo. 2001. Some notes on the Sraffa papers, Cozzi, Terenzio, Marchionatti, Roberto (ed), Piero Sraffa's Political Economy: A Centenary Estimate, part III: 157-164.

De Vivo, Giancarlo. 2015. Review of towards a new understanding of Sraffa. Insights on archival research, in Bellofiore R., Carter S. (ed.), ouv. cite: 125-129.

Garegnani, Pietrangelo. 1998. "Sui manuscriti di Piero Sraffa », Rivista italiana degli economisti, Società editrice il Mulino, issue 1, pp. 151-156, reprint in 2003 (On Piero Sraffa manuscripts) in Kurz Heinz D. and Salvadori, Neri (eds), The Legacy of Piero Sraffa, 2 vol., Cheltenham and Northampton, Edward Elgar: 623-625.

Kurz, Heinz D. 1998. "Against the current: Sraffa's unpublished manuscript in the history of economic thought », European Journal of the History of Economic Thought, ((3): 437-451. 
Kurz, Heinz D. 2009. "Preparing the edition of Piero Sraffa's unpublished papers and correspondence », Cahiers d'économie politique, 57(2): 261-278.

Pasinetti, Luigi G. 2001. Continuity and change in Sraffa's thoughts: an archival excursus, in Cozzi, Terenzio and Marchionatti, Roberto (ed), Piero Sraffa's Political Economy: A Centenary Estimate, London and New York, Routledge, part III: 139-156.

Smith, J., 1988, “An archivist apology: The papers of Piero Sraffa at Trinity College Cambridge," Pensiero economico italiano, Vol. 6: 6-54, reprint in Kurz and Salvadori (eds) 2003.

Smith, J., 2012, "Circuitous processes, jigsaw puzzles, and indisputable results: Masking the best use of the manuscripts of Sraffa's Production of Commodities by Means of Commodities," Cambridge Journal of Economics, Vol. 36, No.6: 1291-1301. 